\title{
Sosialisasi Upaya Meningkatkan Perilaku Keselamatan dan Kesehatan Kerja (K3) pada Nelayan Tradisional di Desa Kawa Kabupatem Seram bagian Barat
}

\author{
La Rakhmat Wabula*1, Ira Sandi Tunny ${ }^{2}$ \\ 1,2Program Studi Ilmu Keperawatan, STIKes Maluku Husada \\ *e-mail: la.rakhmat.wabula.stikesmh@gmail.com ${ }^{1}$, irasandi.99@gmail.com²
}

Nomor Handphone Untuk keperluan koordinasi: 0852-3402-6052

\begin{abstract}
Abstrak
Indonesia adalah negara kepulauan hampir 70\% wilayahnya terdiri dari laut. Kondisi geografis seperti ini sebagian besar penduduk pesisir mempunyai mata pencaharian sebagai nelayan. Masyarakat Desa Kawa adalah 90\% nelayan yang aktivitasnya sebagai penangkap ikan, sangat berisiko terjadinya Kecelakaan Akibat Kerja (KAK) dan Penyakit Akibat Kerja (PAK), penyebab kecelakaan pada nelayan penangkap ikan dapat disebabkan oleh usia kapal/perahu, mesin, cuaca, ombak dan lain-lain. Penyebab penyakit akibat kerja pada nelayan dapat disebabkan oleh air minum, pakaian, kebisingan dan lain-lain. Untuk meningkatkan produktivitas nelayan sangat perlu diterapkan Keselamatan dan Kesehatan Kerja (K3), maka berdasarkan analisis tim pengabdi di Desa Kawa, maka tim melakukan sosialisasi upaya meningkatkan perilaku keselamatan dan kesehatan kerja pada nelayan tradisional dengan metode ceramah. Adapun hasil kegiatan yang dicapai dari kegiatan ini terdapat peningkatan pemahaman yang signifikan terutama pada nelayan tradisional di Desa Kawa tentang upaya meningkatkan perilaku keselamatan dan kesehatan kerja.
\end{abstract}

Kata kunci: Keselamatan dan Kesehatan Kerja (K3), Nelayan Tradisonal

\begin{abstract}
Indonesia is an archipelagic country, almost $70 \%$ of its territory consists of the sea. Geographical conditions like this, most of the coastal population have a livelihood as fishermen. The people of Kawa Village are $90 \%$ of fishermen whose activities are fishing, very at risk of Occupational Effects and Occupational Diseases, the cause of accidents in fishing fishermen can be caused by the age of the ship/boat, engine, weather, waves and etc. The causes of occupational diseases in fishermen can be caused by drinking water, clothing, income, and others. To increase the productivity of fishermen, which really needs to be applied to Occupational Health and Safety, based on the analysis of the service team in Kawa Village, the socialization team made efforts to improve occupational safety and health behavior in traditional fishermen with the lecture method. The results of the activities achieved from this activity experienced a significant increase in understanding, especially for traditional fishermen in Kawa Village about efforts to improve occupational safety and health behavior.
\end{abstract}

Keywords: Occupational Safety and Health, Traditional Fishermen

\section{PENDAHULUAN}

Nelayan adalah sebuah pekerjaan diatas permukaan perairan laut, payau dan perairan tawar dengan melakukan kegiatan antara lain penangkapan ikan, dimana nelayan penangkap ikan berisiko tinggi untuk mengalami Kecelakaan Akibat Kerja ataupun Penyakit Akibat Kerja [1]. Para pakar Keselamatan dan Kesehatan Kerja (K3) dunia mulai memfokuskan upaya peningkatan kinerja dengan program perubahan perilaku K3 yang akhirnya bisa meningkatkan budaya K3 agar tingkat insiden bisa menurun [2].

Berdasarkan data, sebanyak 24.000 nelayan pertahun meninggal dunia dilaut pada kegiatan penangkapan ikan [3]. Laporan tersebut juga menyebutkan bahwa ada 4 faktor yang menjadi penyebab tingginya angka kematian nelayan tradisional dan pengguna transportasi di laut yaitu: (1) rancang bangun perahu yang buruk, (2) perilaku manusia yang tidak sesuai kadangkadang disebabkanoleh kelelaian atau ketidaktahuan, (3) kepedulian terhadap keselamatan yang rendah, serta (4) minimnya ilmu tentang penangkapan ikan dan kepelautan [4]. 
Data statistik tahun 2020 menunjukkan Indonesia terdapat 8 ribu desa pesisir yang tersebar pada 300 kabupaten/ kota pesisir dan dari 234 juta jiwa penduduk Indonesia, 67 juta bekerja pada bidang informal dan 30\% diantaranya adalah nelayan [5]. Penyakit menular tertinggi yang diderita nelayan adalah ISPA, malaria dan pneumonia, sedangkan penyakit tidak menular tertinggi adalah hipertensi, sakit sendi, gangguan emosi, stroke dan Penyakit Jantung Kronis (PJK) [6].

Penduduk Desa Kawa Kabupaten Seram Bagian Barat adalah 80\% nelayan yang aktivitasnya sebagai penangkap ikan, sangat berisiko terjadinya Kecelakaan Akibat Kerja (KAK) dan Penyakit Akibat Kerja (PAK), penyebab kecelakaan pada nelayan penangkap ikan dapat disebabkan oleh usia kapal/perahu, mesin, cuaca, ombak dan lain-lain [7]. Penyebab penyakit akibat kerja pada nelayan dapat disebabkan oleh air minum, pakaian, kebisingan dan lain-lain [8]. Untuk meningkatkan preduktivitas nelayan sangat perlu diterapkan (K3), yang terkait dalam Undang-Undang No. 1 Tahun 1970 tentang Keselamatan Kerja dan dalam Konvensi ILO No. 155 Tahun 1980 tentang Keselamatan dan Kesehatan Kerja (K3) [9]. Masih banyak nelayan tradisional tidak paham tentang kesehatan dan keselamatan kerja saat melaut [10].

Berdasarkan data yang didapatkan di Puskesmas Piru Kabupaten Seram Bagian Barat, didapatkan bahwa sejumlah nelayan di Desa Kawa Kabupaten Seram Bagian Barat menyatakan bahwa penyakit kerap diderita nelayan antara lain: terjadinya kelainan kulit akibat paparan sinar matahari (hiperpigmentasi) baik di muka maupun di tangan, gangguan pendengaran akibat kebisingan yang ditimbulkan masin tempel perahu, serta kelainan mata.

Sosialisasi merupakan upaya yang penting dilakukan untuk meningkatkan pengetahuan nelayan tradisional dalam upaya meningkatkan perilaku kesehatan dan keselamatan kerja [11], maka berdasarkan analisis tim pengabdi di Desa Kawa Kabupaten Seram Bagian Barat untuk diberikan solusi yaitu melakukan Sosialisasi untuk masyarakat awam dengan sasaran adalah masyarakat yang berprofesi sebagai nelayan. Kegiatan ini dilakukan dengan metode tatap muka untuk berinteraksi secara langsung dengan memperhatikan protokol kesehatan.

\section{METODE}

Metode yang dilakukan, yaitu melalui sosialisasi kepada Nelayan Tradisional Desa Kawa Kabupaten Seram Bagian Barat terkait Upaya Meningkatan Perilaku Kesehatan dan Keselamatan Kerja (K3) pada Nelayan Tradisional dengan beberapa cara berikut:

a. Metode observasi lapangan, dilakukan untuk memetakan tempat pelaksanaan kegiatan.

b. Sosialisasi kegiatan, dilakukan di Balai Desa.

c. Sosialisasi Upaya Meningkatan Perilaku Kesehatan dan Keselamatan Kerja (K3) pada Nelayan Tradisional Desa Kawa Kabupaten Seram Bagian Barat.

Berikut beberapa tahapan sosialisasi yang dilakukan oleh tim, sebagai berikut:

a. Tahap I (Observasi Lapangan)

Tim pengabdian melakukan kegiatan observasi lapangan yaitu di Desa Kawa Kabupaten Seram Bagian Barat untuk penentuan lokasi kegiatan.

b. Tahap II (Kegiatan Perizinan)

Tim Pengabdian meminta izin kepada Kepala Kawa Kabupaten Seram Bagian Barat terkait kegiatan sosialiasi yang akan dilaksanakan. Sosialisasi ini bertujuan untuk meningkatkan pengetahuan dalam upaya meningkatkan perilaku Keselamatan dan Kesehatan Kerja (K3) pada nelayan tradisional.

c. Tahap III (Kegiatan Sosialisasi)

Kegiatan dilakukan pada hari Jum'at, 02 Juni 2021 pukul 09.00 WIT. Kegiatan dilakukan dengan metode tatap muka dan tetap memperhatikan protokol kesehatan, menggunakan masker, menerapkan kebiasaan cuci tangan dengan penggunaan hand sanitizer, serta pembatasan jarak. Kegiatan yang dilaksanakan oleh tim dilakukan di Balai Desa Kawa Kabupaten Seram Bagian Barat. 

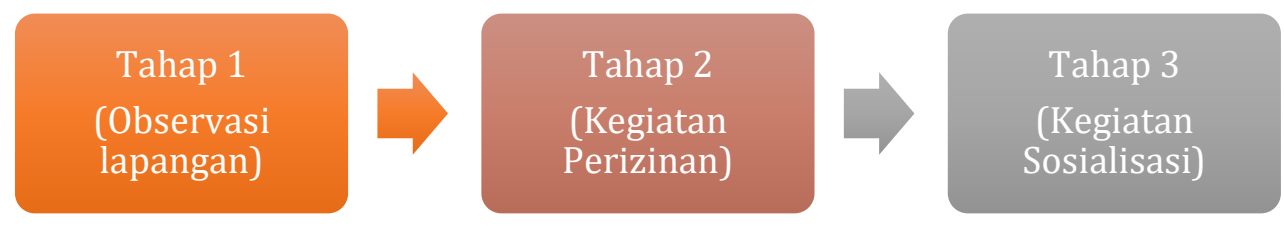

Gambar 1. Alur Kegiatan

\section{HASIL DAN PEMBAHASAN}

Kegiatan sosialisasi dilakukan sebagai upaya peningkatan pengetahuan masyarakat awam di Kawasan pesisir terkhususnya yang berprofesi sebagai nelayan tradisional untuk meningkatkan upaya perilaku Keselamatan dan Kesehatan Kerja (K3) di Desa Kawa Kabupaten Seram Bagian Barat. Kegiatan berlangsung dengan lancar dengan sasaran utama adalah Nelayan Tradisional Desa Kawa Kabupaten Seram Bagian Barat. Kegiatan ini dimulai dari tahap persiapan dan pelaksanaan. Tahap persiapan merupakan tahapan yang cukup panjang guna memperoleh hasil yang baik dan berjalannya kegiatan ini dapat berjalan dengan lancar.

Kegiatan pengabdian masyarakat ini dimulai dari pengumpulan materi dan informasi mengenai upaya meningkatkan perilaku Keselamatan dan Kesehatan Kerja (K3)pada nelayan tradisional. Media yang digunakan yaitu menggunakan Laptop dan LCD yang disajikan dalam bentuk Powerpoint sehingga dapat menarik perhatian dan memudahkan masyarakat untuk memahami isi secara keseluruhan materi dengan baik.

Kegiatan berikutnya merupakan sosialisasi tentang upaya meningkatkan perilaku Keselamatan dan Kesehatan Kerja (K3) pada nelayan tradisional yang dilakukan secara langsung pada sasaran. Pada tahap persiapan dilakukan serangakaian persiapan guna menjadikan tujuan sosialisasi ini tercapai dengan maksimal. Dimulai dengan melakukan kunjungan kepada pihak pemangku desa, yaitu Kepala Desa Kawa Kabupaten Seram Bagian Barat yang dilaksanakan di Balai Desa Kawa. Dari hal tersebut didapatkanlah ijin untuk melaksanakan kegiatan di Desa Kawa dengan diberikannya surat rekomendasi dari pihak desa.

Persiapan selanjutnya adalah dengan menyiapkan bahan-bahan sebagai sarana pendukung sosialisasi tersebut. Pembuatan materi tentang upaya meningkatkan perilaku Keselamatan dan Kesehatan Kerja (K3) pada nelayan tradisional. Hal itu bertujuan untuk memudahkan pelaksana dalam memberikan edukasi dengan gambar dan desain yang menarik sehingga mudah untuk dipahami oleh sasaran.

Pada pelaksanaanya, Nelayan Tradisional Desa Kawa rata-rata masih rendah pengetahuannya terhadap upaya meningkatkan perilaku Keselamatan dan Kesehatan Kerja (K3) pada nelayan tradisional. Kemudian sosialisasi dilaksanakan dengan mengedukasi mereka tentang bagaimana seharusnya bersikap saat melaut. Dari hasil berbincang-bincang dengan beberapa masyarakat didapatkan bahwa sasaran menunjukan tingkat pengetahuan yang lebih baik tentang perilaku Keselamatan dan Kesehatan Kerja (K3) saat melaut. Ketika mereka ditanya mengenai upaya meningkatkan perilaku Keselamatan dan Kesehatan Kerja (K3 pada nelayan tradisional, mereka sudah bisa menjelaskan kembali. Antusiasme ini merupakan semangat bersama untuk belajar bersama sehingga dapat meningkatkan pengetahuan nelayan tradisional dalam upaya peningkatan perilaku Keselamatan dan Kesehatan Kerja (K3) pada nelayan tradisional, kemampuan inilah menjadi salah satu parameter dalam suksesnya kegiatan ini.

Kegiatan sosialisasi kepada Nelayan Tradisional Desa Kawa Kabupaten Seram Bagian Barat dapat dikatakan berjalan dengan lancar dan baik. Kegiatan ini sudah menjawab tujuan awal yaitu memberikan pemahaman yang komprehensi bagi Nelayan Tradisional Desa Kawa dengan memberikan sosialisasi upaya meningkatkan perilaku Keselamatan dan Kesehatan Kerja (K3) pada nelayan tradisional. Dimulai dari pemahaman masing-masing pribadi inilah kemudian diharapkan mereka akan mengimplementasikan dalam kegiatan melaut. Di masa yang akan datang akan lebih baik untuk mengadakan sosialisasi dan simulasi evakuasi medik laut.

Berikut terdapat beberapa foto yang berhasil didokumentasikan pada saat kegiatan berlangsung: 
a. Penerapan protokol kesehatan pada peserta

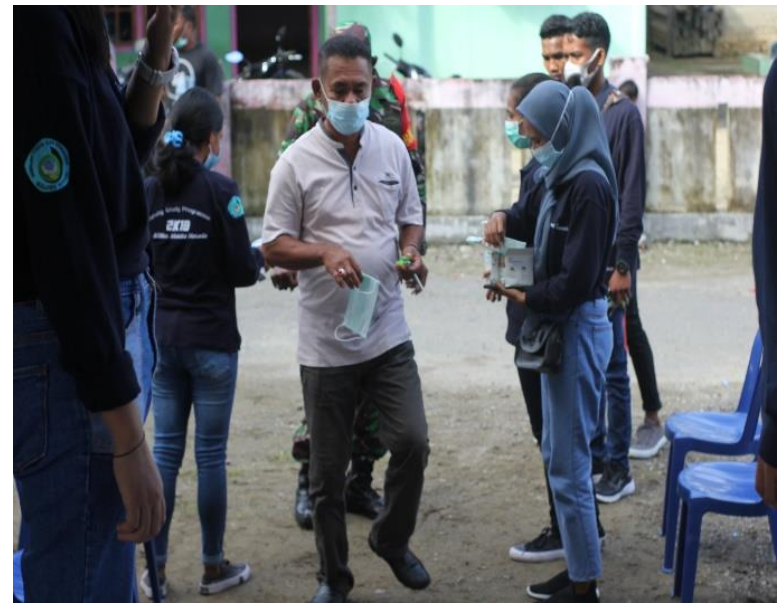

(a)

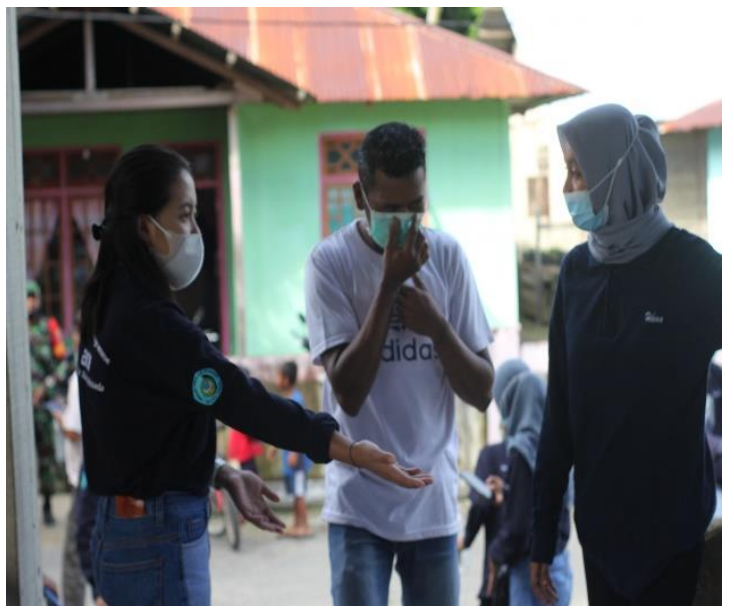

(b)

Gambar 2. (a) dan (b) Penerapan protokol kesehatan pada peserta

Sebelum dimulai kegiatan sosialisasi, tim pengabdian masyarakat melakukan pembagian masker dan meminta peserta untuk mencuci tangan menggunakan hand sanitizer dengan tetap menjaga protokol kesehatan di masa pandemi Covid-19.

b. Screening kesehatan berupa pengukuran Tekanan Darah dan Pemeriksaan Gula Darah Sewaktu

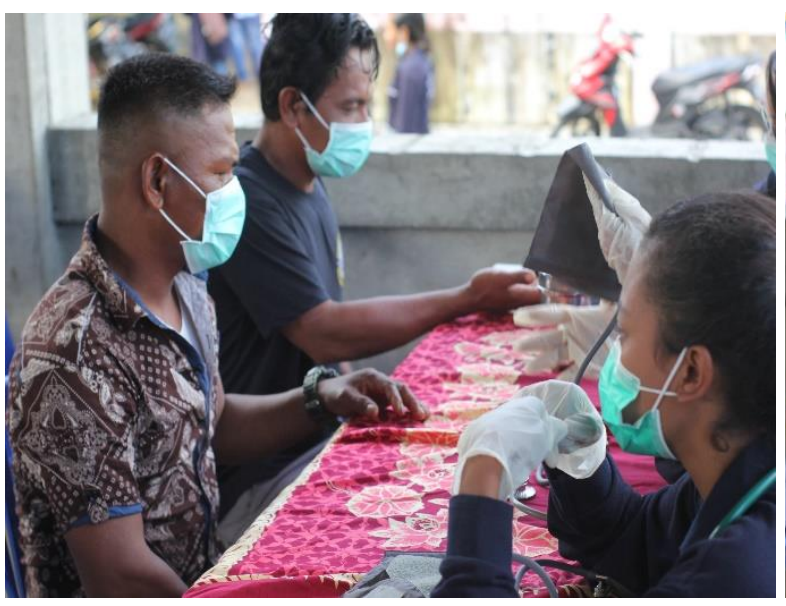

(a)

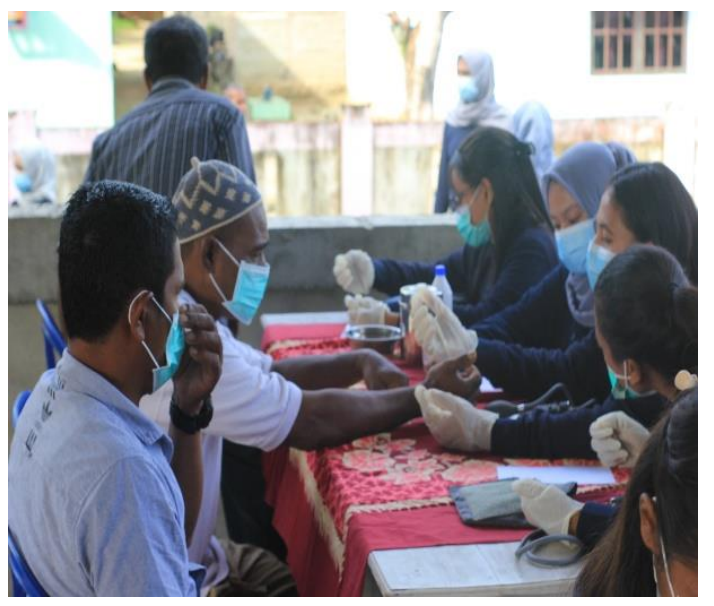

(b)

Gambar 3. (a) dan (b) Screening kesehatan berupa pengukuran tekanan darah dan pemeriksaan gula darah sewaktu

Setelah itu, tim melakukan screening kesehatan berupa pengukuran tekanan darah dan pemeriksaan gula darah sewaktu.

c. Sosialisasi Upaya Peningkatan Perilaku Kesehatan dan Keselamatan Kerja (K3) pada Nelayan Tradisional

Setelah itu, tim melakukan sosialisasi upaya meningkatkan perilaku keselamatan dan kesehatan kerja (K3) yang diikuti oleh 52 nelayan tradisional di Dusun Kawa Kabupaten Seram Bagian Barat. Para peserta sangat antusias dalam mengikuti kegiatan dan aktif bertanya saat pemaparan materi. 


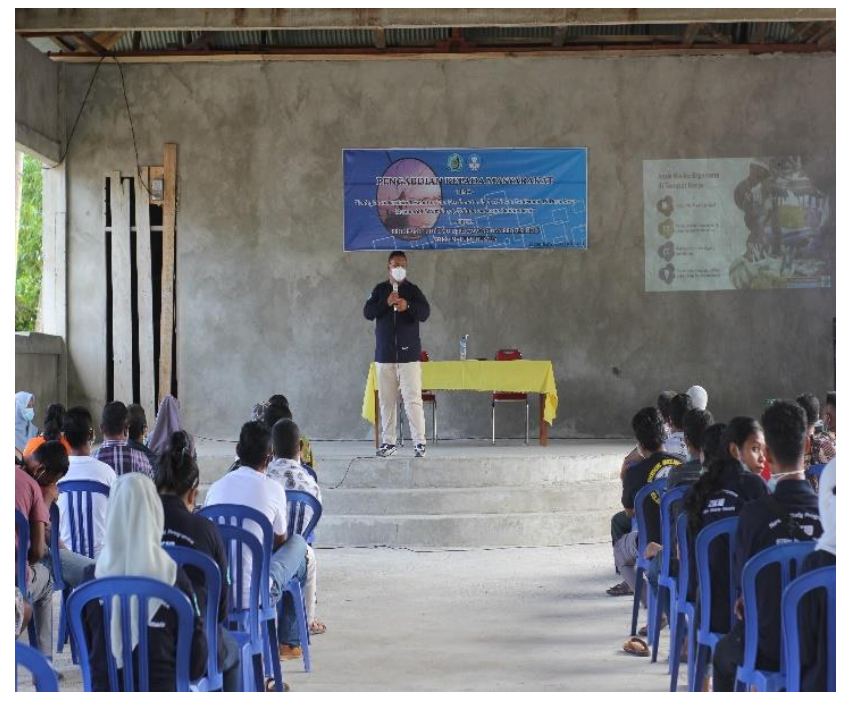

(a)

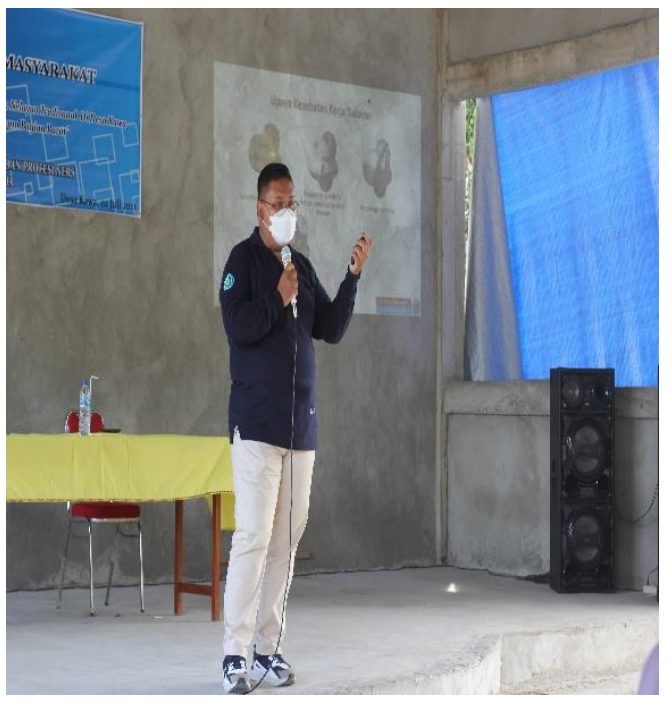

(b)

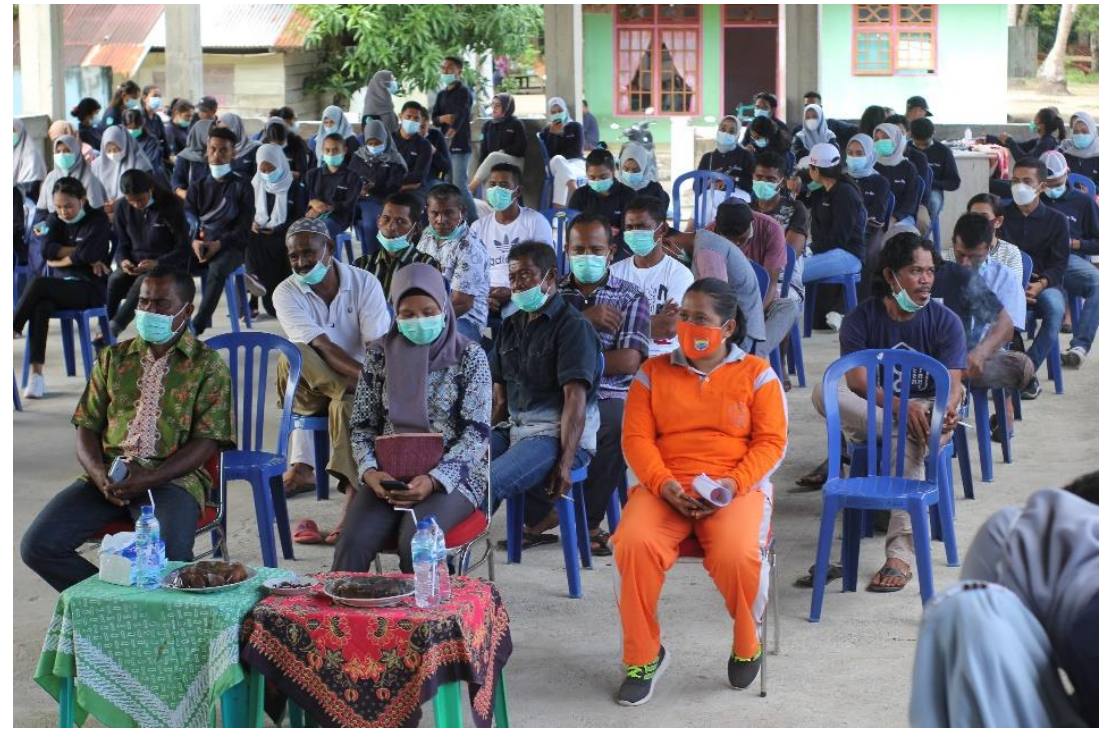

(c)

Gambar 4. (a), (b), (c) Sosialisasi Upaya Meningkatkan Perilaku Keselamatan dan Kesehatan Kerja (K3)

\section{KESIMPULAN}

Bentuk pengabdian masyarakat dengan kegiatan sosialisasi Upaya Meningkatkan Perilaku Keselamatan dan Kesehatan Kerja (K3) pada Nelayan Tradisional di Desa Kawa Kabupaten Seram Bagian Barat dengan tujuan untuk memberikan pemahaman yang benar mengenai Upaya Meningkatkan Perilaku Keselamatan dan Kesehatan Kerja (K3) pada Nelayan Tradisional. Dari pemahaman tersebut munculah kemandirian dari Nelayan Tradisional mengenai Upaya Meningkatkan Perilaku Keselamatan dan Kesehatan Kerja (K3).

\section{DAFTAR PUSTAKA}

[1] P. Markkanen, "Keselamatan dan Kesehatan Kerja di Indonesia," Int. Labour Organ., pp. 153, 2019.

[2] I. Rahman, F. Mallapiang, S. A. Fachrin, and S. H. H. Abbas, "Keselamatan dan Kesehatan Kerja ( K3 ) Sebelum Melaut pada Nelayan Penangkap Ikan di Kelurahan Lappa Kecematan 
Sinjai Utara," J. Kesehat., vol. 2, no. 1, pp. 54-64, 2019.

[3] D. A. Dharmawirawan and R. Modjo, "Identifikasi Bahaya Keselamatan dan Kesehatan Kerja pada Penangkapan Ikan Nelayan Muroami," Kesmas Natl. Public Heal. J., vol. 6, no. 4, pp. 185-192, 2012, doi: 10.21109/kesmas.v6i4.98.

[4] K. Kusnanto, L. R. Wabula, B. Purwanto, H. Arifin, and Y. Kurniawati, "Safety behaviour and healthy diving: A qualitative study in the traditional diverse fishermen," Int. Marit. Health, vol. 71, no. 1, pp. 56-61, 2020, doi: 10.5603/IMH.2020.0012.

[5] I. Rahman, F. Mallapiang, and S. A. Fachrin, "Keselamatan Dan Kesehatan Kerja (K3) Saat Melaut Pada Penangkap Ikan Di Kelurahan Lappa Kecematan Sinjai Utara," J. Ilm. Kesehat. Diagnosis, vol. 13, no. 6, pp. 612-617, 2019.

[6] WHO, State of Health Inequality Indonesia. 2020.

[7] I. M. Syahri and M. Fitria, "Keselamatan Dan Kesehatan Kerja ( K3 ) Pada Nelayan Di Pos Upaya Kesehatan Kerja ( Pos Ukk ) Puskesmas Belawan," Talent. Conf. Ser. Trop. Med., vol. 1, no. 1, pp. 202-206, 2018.

[8] Kementerian Kelautan dan Perikanan, "Rencana Strategis Kementerian Keluatan dan Perikanan Tahun 2020-2024," Kementeri. Kelaut. dan Perikan., 2020.

[9] L. R. Wabula, Perilaku Keselamatan dan Kesehatan Penyelaman pada Penyelam Tradisional Berbasis Health Action Process Aprroach, I., vol. 1, no. 1. Bandung: CV. Cakra, 2020.

[10] O. L. S. Novendey, Ernawati, "Pemeriksaan Kesehatan Paru pada Nelayan di Desa Padegangan Ilir, Tangerang," J. Bakti Masy. Indones., vol. 1, no. 1, pp. 10-16, 2018.

[11] R. D. A Manurung and S. Aryani, "Pendampingan Psikologi Kesehatan Kerja POS Upaya Kesehatan Kerja (UKK) Nelayan Tradisional Tanjung Peni Citangkil Cilegon," J. Abdi Masy., vol. 2, no. 2, pp. 1-6, 2017. 